\title{
CARA PANDANG GURU KRISTEN TERHADAP OTORITAS DALAM KERANGKA KISAH AGUNG
}

\section{Dinda Mawar Sandi dan Cathryne Berliana Nainggolan}

\author{
Universitas Pelita Harapan \\ Jln. M. H. Thamrin Boulevard 1100 Lippo Village, Tanggerang \\ dindamawar66@gmail.com
}

\begin{abstract}
The teacher is an influential person in the classroom. The magnitude of this influence is because the teacher has the authority to be responsible in the classroom. However, not all teachers can exercise their authority in the classroom properly. Teachers treat students too hard or too softly in class so that it takes the teacher's role to be able to carry out their duties with the right authority. Teachers will be able to exercise authority properly if they have the right perspective on authority. The purpose of this paper is to explain the importance of a Christian teacher's perspective in exercising authority in the classroom towards students. The research method used is literature review, using books and journals related to the topic. The teacher's authority is the authority given by God the highest authority. The Great Story is a Biblical framework of creation, fall, redemption, and exaltation. Since the beginning of creation, God has given authority to Adam \& Eve to rule and maintain the earth. This proves that the teacher's authority is a gift from God that must be worked out. The result of writing this paper is that the Christian perspective on authority is the basis for teachers to exercise their authority. This perspective helps Christian teachers understand the source and purpose of the authority given, which is for the glory of God so that the teacher can exercise his authority properly.
\end{abstract}

Keywords: Perspective, Christian teachers, Authority, Framework for the Grand Narrative

\begin{abstract}
Abstrak
Guru merupakan pribadi yang berpengaruh di dalam kelas. Besarnya pengaruh tersebut dikarenakan guru memiliki otoritas untuk bertanggung jawab di dalam kelas. Namun demikian, tidak semua guru dapat menjalankan otoritasnya di dalam kelas dengan baik. Guru memperlakukan siswa terlalu keras atau terlalu lembut di kelas sehingga dibutuhkan peran guru untuk dapat menjalankan tugasnya dengan otoritas yang benar. Guru akan dapat menjalankan otoritas dengan benar jika memiliki dasar cara pandang yang benar pula mengenai otoritas. Tujuan dari makalah ini untuk menjelaskan pentingnya cara pandang guru Kristen dalam menjalankan otoritas di kelas terhadap siswa. Metode penelitian yang digunakan adalah kajian pustaka, dengan menggunakan buku dan jurnal yang terkait dengan topik. Otoritas guru merupakan otoritas yang diberikan oleh Tuhan sang pemegang otoritas tertinggi. Kisah Agung adalah kerangka pikir Alkitab yang terdiri dari penciptaan, kejatuhan, penebusan, dan pemuliaan. Sejak awal penciptaan, Tuhan sudah memberikan otoritas kepada
\end{abstract}


Adam dan Hawa untuk menguasai dan memelihara bumi. Hal tersebut membuktikan bahwa otoritas yang dimiliki guru adalah pemberian Tuhan yang harus dikerjakan. Hasil dari penulisan makalah ini adalah cara pandang Kristen terhadap otoritas adalah dasar guru menjalankan otoritasnya. Cara pandang tersebut membantu guru Kristen memahami sumber dan tujuan otoritas yang diberikan yaitu untuk kemuliaan Allah sehingga guru dapat mempraktikkan otoritasnya dengan benar.

Kata Kunci: Cara Pandang, Guru Kristen, Otoritas, Kerangka Kisah Agung

\section{PENDAHULUAN}

Guru sebagai pemegang otoritas di kelas berperan penting dalam proses dan tujuan pembelajaran yakni untuk mendidik siswa secara kognitif, afektif, dan psikomotorik, dan untuk mengubah sikap dalam memahami sesuatu yang baru ${ }^{1}$. Guru harus mampu menjalankan otoritasnya dalam proses pembelajaran sehingga guru dapat mencapai tujuan belajar. Ketercapaian tujuan pembelajaran dapat menunjukkan keberhasilan suatu proses pembelajaran yang diikuti siswa maupun guru yang merencanakan pembelajaran. ${ }^{2}$

Kajian otoritas guru dikembangkan dari pemikiran John Wilson yang melihat otoritas dalam hubungan dengan pendidikan yaitu otoritas praktis dan teoritis. Otoritas praktis memiliki keterkaitan dengan tindakan guru seperti mendisiplinkan siswa, memberi hukuman, memberi instruksi dan mengarahkan siswa. ${ }^{3}$ Otoritas teoritis yaitu proses guru mengajar siswa untuk menemukan informasi dan memperlengkapi siswa dengan ilmu pengetahuan serta keterampilan. ${ }^{4}$ Hal tersebut menggambarkan tugas guru untuk menjalankan otoritasnya dengan baik dan maksimal.

Beberapa pelaksanaan otoritas yang baik dalam pembelajaran di kelas yaitu pertama, kedisiplinan yang diberikan guru kepada siswa memiliki alasan benar yang berisi kasih dan keadilan. ${ }^{5}$ Guru sebagai pemegang otoritas di kelas memiliki hak untuk memberikan aturan yang mendisiplinkan siswa tetapi tidak menghilangkan kasih. Kedua, guru memiliki tanggung jawab yang penuh termasuk kepada Tuhan atas segala sesuatu yang dilakukan di kelas termasuk kedisiplinan yang dibangun. ${ }^{6}$ 
Berdasarkan dua prinsip pelaksanaan kedisiplinan dalam otoritas guru tersebut di atas, peneliti menyimpulkan bahwa guru memiliki otoritas untuk bertanggung jawab dalam semua kegiatan proses pembelajaran.

Kegiatan proses pembelajaran tidak terlepas dari banyak masalah yang terjadi di kelas seperti tidak berjalannya proses pembelajaran. Masalah di dalam proses pembelajaran dapat datang dari kedua pihak: pihak guru dan pihak siswa. Guru terlalu menuntut murid secara berlebihan dan tidak menghiraukan kesulitan yang dihadapi murid. ${ }^{7}$ Tuntutan tanpa bimbingan dari guru juga merupakan masalah bagi siswa, karena tidak semua siswa mampu berjalan sendiri tanpa ada bimbingan atau kontrol dari guru. Guru yang terlalu menuntut memiliki dasar pemahaman dalam dirinya sehingga membuat guru tersebut melakukan tuntutan yang terlalu keras. Dasar pemahaman guru berbeda-beda, mungkin dasar atau alasan yang dimiliki guru benar atau sebaliknya dan hal itu mempengaruhi praktik guru dalam menjalankan otoritasnya. Selain dari pihak guru, masalah juga sering ditimbulkan oleh siswa. "Beberapa contoh pelanggaran tersebut, seperti menyontek, tidak mengerjakan tugas sekolah, melanggar peraturan sekolah, membolos, pemalakan, perkelahian, dan penganiayaan sesama siswa."

Fakta juga ditemukan oleh penulis S. Yugo Hindarto dalam berita yang dipublikasikan oleh CNN Indonesia, guru dari salah satu SMP di Pangkal Pinang menganiaya siswa dengan tamparan dan membenturkan kepala siswa ke dinding karena siswa dengan sengaja memanggil gurunya tidak menggunakan awalan kata "pak" sehingga membuat guru emosi. ${ }^{9}$ Fakta yang terdapat dalam berita tersebut merupakan salah satu contoh praktik guru yang salah atau berlebihan dalam memberikan konsekuensi terhadap siswa.

Konsep kerangka Kisah Agung memberikan suatu pemahaman akan otoritas Tuhan dalam kehidupan manusia dari awal penciptaan hingga akhir pada masa kekekalan. Alkitab adalah Kisah Agung, sebagaimana diartikulasikan oleh para ahli di bidang studi biblika dan misiologi tentang Tuhan: sebuah sejarah yang mencatat aktivitas Tuhan dalam menciptakan, menebus, menguduskan gerakan di, dengan, dan melalui umat manusia dari awal hingga akhir. ${ }^{10}$ Glasser dan C. Wright adalah sarjana alkitabiah dan misiologi. Wright dengan singkat menyatakan, bahwa Kisah Agung 
ini sering disajikan sebagai kisah empat poin: penciptaan, kejatuhan, penebusan, dan harapan masa depan. ${ }^{11}$ Penciptaan yang memperlihatkan Tuhan menciptakan alam semesta dan segala isinya, kejatuhan memperlihatkan saat manusia jatuh ke dalam dosa, penebusan membawa manusia memahami pengorbanan Tuhan untuk menebus umat-Nya dan akan sampai pada masa pemuliaan.

Kerangka Kisah Agung menjadi cara pandang Kekristenan yang menjadi lensa melihat setiap realitas. Kisah Agung adalah kerangka Alkitab yang menggambarkan Allah sebagai realitas ultimate eksistensi manusia dan alam semesta. "Allah dengan kekuatan Firman dan Roh-Nya telah menciptakan langit dan bumi dari ketiadaan, dan bahwa dari langit dan bumi itu telah dibuat-Nya segala jenis binatang serta ciptaan yang tak bernyawa bahwa telah dibeda-bedakan-Nya, dengan tertib yang mengagungkan, keanekaragaman benda yang tak terhingga yang kita lihat itu, bahwa setiap jenis diberi-Nya sifat sendiri, bahwa telah ditetapkan-Nya tugas mereka, bahwa telah ditentukan-Nya tempat dan rumah bagi mereka." ${ }^{12}$ Penciptaan yang Allah kerjakan begitu sempurna dan rinci dalam setiap bagiannya. Hal tersebut menunjukkan bahwa Allah merancangkan sedemikian rupa segala yang diciptakannya. Allah menciptakan manusia dan memperlengkapinya dengan karuniakarunianya, hal tersebut memperlihatkan bahwa Allah telah memberikan contoh yang paling unggul dari seluruh karya-Nya. ${ }^{13}$ Ketika Allah menciptakan manusia dan alam semesta memperlihatkan betapa Allah adalah otoritas tertinggi yang berdaulat atas ciptaan-ciptaan-Nya.

Penciptaan manusia yang Allah lakukan baik adanya dengan keadaan tidak ada keinginan untuk berbuat dosa. Tetapi akibat kejatuhan dan ketidaktaatan Adam dan Hawa, dosa mulai masuk ke dalam dunia. ${ }^{14}$ Pekerjaan tangan Allah tidak sampai pada proses Allah menciptakan dunia dan segala isinya tetapi Allah Bapa mengirimkan anak-Nya yaitu Yesus Kristus untuk menebus dosa manusia akibat kejatuhan. Yesus Kristus adalah satu-satunya Penebus bagi umat pilihan Allah. ${ }^{15}$ Kejatuhan membawa manusia tidak mampu taat dan melakukan hal baik serta tidak mampu menyelamatkan dirinya sendiri. Yesus Kristus berkarya dalam kerangka sejarah penebusan, hal tersebut dimulai dengan hubungan manusia pertama yang sebagai kepala manusia yang pertama yaitu Adam dengan keturunannya. ${ }^{16}$ Akibat 
kejatuhan kemampuan manusia untuk berbuat kebaikan hilang, tetapi penebusan membawa pemulihan. ${ }^{17}$ Proses penebusan memperlihatkan betapa tiada yang lain selain Allah yang mampu menyelamatkan manusia dari dosa hingga nanti sampai pada masa pemuliaan di mana Allah memulihkan umat pilihan-Nya. "Suatu hari kelak setelah kebangkitan tubuh, orang Kristen akan bebas secara sempurna dan total." $"$ Penjelasan tentang otoritas terutama otoritas guru dan kisah Agung mengarahkan pada satu tujuan penulisan ini. Tujuan makalah ini untuk menegaskan kembali cara pandang Kisah Agung yang dapat menjadi solusi agar guru dapat mempraktikkan otoritasnya dengan benar dan tepat di dalam kelas.

\section{METODE PENELITIAN}

Metode penelitian yang digunakan oleh penulis adalah kajian literatur atau kajian pustaka. Sebuah kajian pustaka merupakan sebuah uraian atau deskripsi tentang literatur yang relevan dengan bidang atau topik tertentu. Kajian pustaka memberikan tinjauan mengenai apa yang telah dibahas atau dibicarakan oleh penulis, teori dan hipotesis yang mendukung, permasalahan yang diajukan atau ditanyakan, metode dan metodologi yang sesuai. ${ }^{19}$ Melalui metode ini penulis mencoba mengungkapkan temuannya. Sumber data dari penulisan ini diambil dari buku dan jurnal yang memiliki hubungan erat dengan topik yang dibahas oleh penulis.

\section{HASIL DAN PEMBAHASAN}

\section{Cara Pandang Guru Kristen}

Cara pandang dunia memiliki pengertian sebagai seluruh rangkaian dari kepercayaan dasar manusia dalam melihat atau mendefinisikan segala sesuatu. ${ }^{20} \mathrm{Cara}$ pandang akan membentuk suatu kepercayaan terhadap segala sesuatu yang dilihat oleh manusia. Sudut pandang yang mendasari pemikiran tentang manusia memiliki pengaruh pada dasar pemikiran dan tindakan-tindakan dalam pendidikan. ${ }^{21}$ Kedua teori yang dikemukakan oleh penulis tersebut dapat disimpulkan bahwa manusia yang memiliki cara pandang dan kepercayaan dalam dirinya maka akan membentuk suatu tindakan yang akan dilakukan berdasarkan apa yang sudah dipercayai. Salah 
satu contoh seorang guru dalam pendidikan, secara spesifik guru Kristen juga memiliki cara pandang yang menghasilkan suatu tindakannya di dalam kelas.

Guru Kristen memiliki cara pandang dalam melihat sesuatu berdasarkan Biblical Christian Worldview. "Cara pandang Kristiani terdiri dari sekumpulan kepercayaan Kristen yang fundamental yang paling mumpuni dalam menjelaskan hubungan antara Allah dan ciptaan."22 Guru Kristen dalam mengerjakan apapun dilihat dari sudut pandang Allah sebab kebenaran hanya ada pada Allah. Kebenaran menjadi dasar bagi cara pandang manusia terhadap dunia dan cara pandang tersebut yang akan menjadi dasar bagi tindakan serta perilaku manusia. ${ }^{23}$ Penjelasan tentang dasar kebenaran melalui teori tersebut merupakan landasan guru Kristen dalam mengajar dengan cara pandang yang benar.

Cara pandang guru Kristen sangat luas seperti cara pandangnya terhadap siswa, kelas, relasi antara guru, strategi pembelajaran yang akan dipakai dan sebagainya. Tidak hanya tugas dan panggilan yang dikerjakan tetapi cara pandang dan dasar yang dipegang oleh guru Kristen juga harus dipertanggungjawabkan di hadapan Tuhan. Hal tersebut memperlihatkan bahwa guru Kristen dalam melakukan tanggung jawabnya memiliki tujuan yaitu untuk memuliakan Tuhan yang ditunjukkan dari pertanggungjawabannya kepada Tuhan. "Peran guru Kristen sebagai pendidik dituntut memiliki panggilan yang jelas dan penyerahan yang total dalam mengajar seperti halnya melayani Tuhan, yang berdampak kepada kerja keras dengan tujuan untuk memuliakan-Nya."24

Berdasarkan penjelasan di atas bahwa cara pandang seseorang mempengaruhi kepercayaan dan tindakannya sehingga perlu memiliki cara pandang yang benar untuk menghasilkan tindakan dan kepercayaan yang benar. Cara pandang seseorang dalam memandang dunia mempengaruhi, membangun cara hidup dan membawa kepada apa yang dipercayai. ${ }^{25}$ Teori ini lebih dalam menjelaskan bahwa cara pandang bukan hanya mempengaruhi kepercayaan seseorang tetapi juga cara hidupnya. Contoh yang diberikan di atas adalah guru Kristen, jika dihubungkan dengan pernyataan teori ini maka dapat disimpulkan bahwa cara pandang guru Kristen mempengaruhi kepercayaan, tindakan, dan cara hidup guru Kristen. 
Cara pandang guru Kristen tidak terlepas dari identitas guru Kristen sendiri. Identitas guru Kristen yaitu guru yang telah lahir baru dan mengalami pertumbuhan iman. Iman tidak dapat terlepas dari lahir baru karena melalui iman guru mengalami lahir baru. Iman adalah ketaatan kepada Allah. ${ }^{26}$ Tanggung jawab yang dimiliki seorang guru Kristen harus dikerjakan dengan penuh ketaatan kepada Allah. Iman harus bertumbuh dalam diri guru Kristen sebelum guru Kristen membantu siswa untuk melihat pertumbuhan imannya. Guru harus mempunyai iman dan hal itu sangat penting untuk pertumbuhan profesional pribadinya karena guru akan mengajar untuk sebuah panggilan pelayanan yaitu membuat terang oleh hadiah Tuhan yang telah diberikan kepada guru. ${ }^{27}$ Melalui identitas yang dimiliki guru Kristen memampukan guru Kristen untuk memiliki cara pandang yang berpusat kepada Kristus dan dalam melakukan tanggung jawabnya sebagai orang yang berotoritas di kelas berdasarkan kebenaran firman Allah.

\section{Kisah Agung}

Sejak semula manusia mengetahui bahwa manusia diciptakan dari debu tanah dan Allah sendiri yang membentuk manusia. Allah menciptakan manusia serupa dan segambar dengan Allah dan memampukan manusia untuk melakukan kehendakNya. ${ }^{28}$ Pembentukan Allah dalam menciptakan manusia, membuat manusia mengenal Allah dan menyadari keberadaan-Nya. Manusia diciptakan oleh Allah dalam keadaan tidak berdosa. ${ }^{29}$ Pada waktu penciptaan manusia dikatakan unik karena pada waktu itu hanya manusia sebagai satu-satunya penghuni bumi yang dikhususkan Tuhan untuk bertanggung jawab dengan kewajibannya (Kejadian 1:28). ${ }^{30}$ Pada kerangka Kisah Agung yang diawali dengan peristiwa penciptaan, manusia pada mulanya diciptakan baik adanya dan bahkan satu-satunya ciptaan yang diberikan kuasa dan tanggung jawab terhadap ciptaan lainnya.

Kejatuhan manusia dalam dosa atas ketidaktaatannya terhadap perintah dan tanggung jawab yang Allah berikan membuat manusia mengalami keterpisahan relasi dengan Allah. Manusia yang jatuh sedang dalam pemberontakan aktif melawan Penciptanya. Manusia memiliki kecenderungan untuk berada pada posisi Tuhan dan tidak menaati hukum alam semesta. ${ }^{31}$ Alkitab menyatakan setiap manusia yang jatuh 
dikatakan sebagai seorang yang memberontak yang tidak dapat dengan sendirinya menemukan Allah Sang Pencipta. ${ }^{32}$ Akibat kejatuhan membuat manusia cenderung hidup untuk dirinya sendiri dan melakukan sesuatu atas dasar dirinya sendiri tetapi hal tersebut membuat manusia tidak mampu berdamai dengan Allah dengan usahanya sendiri. Semenjak manusia jatuh dalam dosa, manusia tidak mampu berbuat kebaikan dan memiliki kecenderungan untuk melakukan kejahatan sehingga tanpa anugerah Allah manusia tidak dapat melakukan hal baik apapun. ${ }^{33}$

Manusia membutuhkan Allah untuk menyelamatkannya dari dosa dan berdamai dengan-Nya. Dasar orang percaya dapat mengalami rekonsiliasi dengan Allah adalah penebusan Yesus Kristus, hal tersebut merupakan karya Allah dan telah ditegaskan di dalam Alkitab. ${ }^{34}$ Penebusan Kristus menjadikan manusia berdosa mengalami rekonsiliasi dengan Allah dan memperoleh hidup yang kekal di dalam Kristus. ${ }^{35}$ Melalui penebusan Yesus Kristus manusia berdosa dapat diperdamaikan dengan Allah. Pemuliaan ciptaan terletak di dalam karya Kristus dan di dalam

Kristus seluruh ciptaan dipersatukan dengan Sang Pencipta. ${ }^{36}$ Allah telah menebus manusia dan pada akhirnya nanti sampai pada proses pemuliaan, di mana segala yang diciptakan dipulihkan oleh Allah sang pemegang otoritas tertinggi.

\section{Otoritas dalam Kisah Agung}

Otoritas adalah suatu kewenangan yang dimiliki seseorang untuk berkuasa, memimpin dan memerintah dalam suatu bidang tertentu. "Menurut definisi umum, wewenang (authority) adalah hak untuk melakukan sesuatu atau memerintah orang lain untuk melakukan atau tidak melakukan sesuatu agar tercapai tujuan tertentu.",37 Sumber dari semua otoritas yang ada di dunia ini adalah dari Allah. Allah adalah pemegang otoritas tertinggi karena Allah sebagai Sang Pencipta segala sesuatu di dunia. Setiap otoritas yang dimiliki manusia adalah anugerah dari Allah ${ }^{38}$ Allah memberikan otoritas kepada manusia untuk sebuah tujuan. Tujuan tersebut adalah membuat manusia belajar dan memuliakan Allah dengan otoritas yang dimilikinya. Otoritas tertinggi tidak terbatas, tetapi otoritas manusia di dunia terbatas. Semua otoritas yang ada di dunia berada dalam kontrol dan batasan dari Allah. Manusia 
adalah ciptaan terbatas yang perlu pertolongan Allah dan setiap otoritas yang dimiliki manusia merupakan ketetapan Allah yang memiliki batasan dari Allah. ${ }^{39}$

Penciptaan (creation), kejatuhan (fall), penebusan (redemption), dan pemuliaan (glorification) merupakan bagian dari kerangka Kisah Agung. Kerangka Kisah Agung dimulai dari proses penciptaan. Penciptaan segala sesuatu yang ada di dunia termasuk penciptaan manusia. Manusia di dunia merupakan kawan sekerja Allah yang diciptakan menurut gambar Allah dan memiliki kekuasaan di bumi untuk menjadi wakil Allah. ${ }^{40}$ Proses penciptaan merupakan proses ketika manusia menerima otoritas pertama untuk berkuasa atas ciptaan lain dari Allah. Hal tersebut terlihat dari manusia pertama yang Allah ciptakan yaitu Adam untuk berkuasa dan mengolah taman Eden. Adam dilatih untuk menjadi pemimpin di taman Eden, untuk memiliki kepemimpinan yang kreatif, peduli dan berotoritas (Kejadian 2:15). ${ }^{41}$

Konsep otoritas sebenarnya sudah ada sejak zaman penciptaan. Manusia diciptakan Allah memiliki tujuan kekal yaitu melakukan tugas dan tanggung jawabnya dalam menyatakan cinta kasih Allah. ${ }^{42}$ Proses penciptaan membuat manusia menjadi sadar akan otoritas tertinggi di atasnya yaitu Allah, sehingga manusia belajar untuk tunduk kepada Allah dan mengenal-Nya. Otoritas yang dimiliki manusia adalah sebuah pemberian dan Allah sendiri yang akan memampukan manusia melakukan tugasnya. Manusia diciptakan Allah memiliki bakat untuk terus belajar dan menumbuhkan pengetahuan sehingga membuat manusia mengenal Allah. ${ }^{43}$ Pengetahuan manusia semakin hari akan semakin berkembang dalam proses belajarnya. Manusia yang menyadari perkembangan pengetahuan itu berasal dari campur tangan Allah maka manusia juga akan semakin mengenal Allah.

Kejatuhan merupakan peristiwa jatuhnya manusia ke dalam dosa. "Kejatuhan manusia ke dalam dosa membuat manusia tidak mampu mengenal seperti yang dikehendaki Allah Sang Pencipta, setiap hari manusia diperhadapkan dengan pilihan di setiap tindakannya." ${ }^{44}$ Manusia mulai menyalahgunakan otoritasnya sehingga manusia jatuh dalam dosa melalui setiap perbuatannya. Mulai dari manusia pertama yang jatuh dalam dosa membuat maut terus menguasai segenap umat manusia. ${ }^{45}$ Manusia hanya berfokus pada otoritasnya di bumi dan menggunakan otoritasnya atas 
dasar untuk dirinya sendiri bukan untuk Allah bahkan melalui otoritas yang dimiliki membuat manusia tidak tunduk kepada otoritas Allah. Manusia menjadi berubah akibat dari kejatuhan manusia dalam dosa seperti yang ditulis dalam Kejadian 3. Manusia berjalan dengan jalannya sendiri dan menolak Tuhan. ${ }^{46}$

Proses kejatuhan membuat manusia menyalahgunakan otoritas yang Allah berikan dan manusia jatuh dalam dosa, Allah mengutus anak-Nya yaitu Yesus Kristus untuk menebus manusia yang berdosa melalui kematian-Nya di kayu Salib. Alasan Kristus datang ke dunia adalah inisiatif Tuhan sendiri untuk menyelamatkan manusia yang hilang dan memperbaiki serta mengembalikan gambar dan rupa-Nya yang telah rusak. ${ }^{47}$ Manusia menyadari keberdosaannya dengan tindakan yang telah dilakukan. Manusia ingin menjadi tuhan atas dirinya sendiri karena otoritas yang dimilikinya. Kehadiran Allah menyatakan terang, keteraturan dan pengharapan bahkan ketika keputusasaan berada dimana-mana. ${ }^{48}$

Proses penebusan membuat manusia sadar akan keterbatasannya, bahwa ada otoritas di atasnya yang berkuasa melakukan segala sesuatu. Manusia yang telah ditebus semakin hari semakin diperbaharui, meskipun masih bisa jatuh dalam dosa tetapi tidak hidup di dalam dosa melainkan bertobat kembali kepada Allah. Manusia tidak sempurna dalam menjalankan otoritasnya dalam kehidupan tetapi manusia berusaha untuk melakukan yang terbaik. Dalam Perjanjian Baru kita mendengarkan kabar sukacita, bahwa setiap pengorbanan Yesus Kristus telah menjadikan transformasi total, yakni pemulihan kembali relasi yang erat antara Allah dan manusia. ${ }^{49}$ Hubungan yang terjalin baik kembali antara Allah dan manusia, membuat manusia belajar untuk memperbaiki diri untuk menjadi serupa dengan Kristus.

Proses selanjutnya adalah proses terakhir yaitu pemulihan (glorification) dalam kerangka Kisah Agung. Pemuliaan adalah langkah terakhir dalam penerapan penebusan. ${ }^{50}$ Pemuliaan dialami oleh kehidupan orang Kristen sampai selesai dalam kedatangan Kristus. ${ }^{51}$ Proses ini adalah proses akhir kehidupan manusia dan hanya Allah yang tahu. Proses pemulihan memperlihatkan betapa sempurna dan besarnya otoritas yang dimiliki Allah sehingga dapat memegang kehidupan manusia dari awal manusia ada melalui penciptaan sampai pada manusia pada akhirnya nanti. Proses ini akan menyadarkan manusia akan otoritas tertinggi dan bahwa otoritas dari Allah 
yang dimilikinya adalah kekuasaan terbatas yang tujuannya untuk melakukan tugas dan tanggung jawab dari Allah dan bukan untuk memegahkan diri. ${ }^{52}$ Karya kebangkitan yang kuat ini akan menghasilkan penyelesaian keselamatan yang dimulai dalam kehidupan orang Kristen, suatu pemuliaan yang dengan sendirinya dijamin dan dilakukan oleh Roh Kudus. ${ }^{53}$

\section{Cara pandang guru Kristen terhadap otoritas Allah}

Pada bagian latar belakang tulisan ini telah disebutkan bahwa terdapat beberapa masalah dalam eksekusi otoritas oleh guru di dalam kelas. Fakta tersebut membuat guru harus mengetahui betapa pentingnya memahami otoritas yang dipercayakan padanya. Pemahaman guru terhadap otoritas terlihat dari dasar dan cara pandangnya dalam memandang otoritas sehingga hal itu mempengaruhi tindakannya. Oleh sebab itu, tujuan dari makalah ini adalah memperlihatkan pentingnya cara pandang guru Kristen terhadap otoritas.

Cara pandang mengenai otoritas yang harus dipahami oleh guru Kristen yaitu otoritas merupakan pemberian Allah dan akan kembali kepada Allah. Tujuan otoritas yang dimiliki manusia adalah untuk memuliakan Allah. Tujuan otoritas guru Kristen adalah memuliakan Tuhan dalam setiap tanggung jawab yang dimilikinya di kelas. Praktik seorang guru yang memiliki pemahaman dan tujuan benar terhadap otoritas adalah guru yang akan mampu menjalankan otoritasnya dengan baik. Salah satu contoh tindakan guru yang memiliki pemahaman dan tujuan yang benar terhadap otoritas yaitu guru dapat mampu memberitahukan kepada setiap siswa tentang tindakan jahat merupakan tindakan dosa yang melawan Allah untuk itu perlu mengoreksi dan mendisiplinkan siswa. ${ }^{54}$ Hal tersebut merupakan salah satu tindakan guru yang memperlihatkan otoritasnya di dalam kelas dengan mengarahkan siswa kepada sebuah kebenaran.

Dasar cara pandang guru Kristen adalah kebenaran firman Allah. Guru Kristen juga harus tahu dasar kebenaran yang membawanya memahami konsep otoritas yaitu firman Allah. Pada dasarnya guru Kristen mengalami lahir baru melalui iman dan pertobatan dalam hidupnya sehingga diharapkan guru mampu membawa siswa kepada kebenaran. Kebenaran yang dapat membentuk siswa dalam segala 
aspek dalam hidupnya. Lahir baru adalah awal hidup yang baru yang diberikan Roh Kudus dalam diri manusia, sehingga membuat manusia bertobat dan percaya dengan iman. ${ }^{55}$ Lahir baru membawa guru Kristen dapat memiliki dasar yang benar dalam melakukan suatu tindakan karena didasari oleh iman dan pertobatan dalam hidupnya. Guru Kristen, guru yang sudah lahir baru dan menjadi teladan dalam kehidupan yang bergantung kepada Tuhan, hal tersebut memberi gambaran bahwa guru-guru bekerja bersama Tuhan. ${ }^{56}$

Dasar pemahaman guru Kristen sebagai otoritas dimulai dari pemahaman tentang sumber dari semua otoritas di dunia. Guru harus mengetahui bahwa sumber dari semua otoritas adalah Allah. Allah Sang Pencipta sebagai pemegang otoritas tertinggi. "Salah satu dasar presaposisi dari pandangan Kristen tentang manusia adalah adanya kepercayaan dalam diri manusia kepada Allah sebagai Pencipta.,57 Pemahaman guru tentang Allah sebagai otoritas tertinggi merupakan salah satu dasar teologi yang dibangun oleh guru dalam menjalankan otoritasnya di dalam kelas.

Guru juga harus memiliki pemahaman tentang keterkaitan otoritas mula-mula dalam kerangka Kisah Agung. Guru harus paham mengenai konsep otoritas dalam kerangka kisah Agung Allah yang dimulai dari penciptaan sampai pada pemuliaan. Otoritas muncul pertama pada waktu penciptaan, dimana Allah memberikan kuasa untuk memelihara taman Eden kepada manusia pertama. Hal tersebut memperlihatkan bahwa otoritas manusia yang diberikan bermula dari proses penciptaan dan sampai pada masa sekarang. Proses kedua adalah masa kejatuhan, dimana manusia menyalahgunakan otoritasnya sehingga manusia jatuh dalam dosa. Manusia tidak mau tunduk kepada otoritas Tuhan dan manusia menggunakan otoritasnya di luar batas yang sudah ditentukan.

Manusia tidak dapat menyelamatkan dirinya dari dosa sehingga harus ada sesuatu di luar diri manusia yang dapat menyelamatkan manusia dari dosa. Doktrin keselamatan memberikan suatu pengetahuan mengenai Allah sebagai sumber tertinggi dalam kehidupan manusia sehingga hidup manusia bergantung penuh kepada Allah dari sekarang sampai pada masa yang akan datang. ${ }^{58}$ Allah sanggup menyelamatkan manusia dari dosa karena Allah pemegang kehidupan manusia. Dasar Allah menyelamatkan orang berdosa dituliskan di dalam Alkitab yaitu karena 
kasih dan keadilan Allah yang dinyatakan. ${ }^{59}$ Otoritas Allah tidak pernah melepaskan kasih dan keadilan karena hal itu sangat terkait. Melalui kasih dan keadilan akan terlihat otoritas Allah yang sempurna.

Proses ketiga adalah penebusan, di mana otoritas Allah ditegakkan melalui Yesus Kristus untuk menyelamatkan manusia yang sudah jatuh ke dalam dosa karena pelanggarannya terhadap penyalahgunaan otoritas. Yesus Kristus bukan hanya otoritas tertinggi yang menebus dosa manusia tetapi juga menjadi teladan utama bagi guru-guru Kristen yang mempunyai otoritas di dalam kelas untuk membawa pemahaman siswa mengenal firman Tuhan dan mengalami pembaharuan yang baik terus-menerus dalam setiap pengajarannya. Seorang guru juga masih dapat jatuh dalam dosa, tetapi penebusan membawa guru untuk terus diperbaharui menjadi serupa dengan Kristus. Siswa butuh guru untuk membangun pemahamanpemahaman yang benar dalam hidupnya. Hal tersebut sudah terlebih dulu dilakukan oleh Yesus Kristus kepada murid-Nya. Pengajaran Yesus punya tujuan terhadap murid-Nya yaitu menggerakkan murid-Nya dari level pemahaman mereka yang sebenarnya sampai diwujudkan pada level dari kesanggupan pemahaman dari firman Tuhan. ${ }^{60}$ Proses yang terakhir adalah proses pemuliaan, proses ini membawa manusia untuk melihat kebesaran otoritas tertinggi. Allah yang berdaulat atas hidup manusia dalam proses ini, karena proses tersebut hanya dikerjakan oleh Allah. Otoritas mula-mula dan otoritas tertinggi adalah dasar penting yang harus dipahami oleh guru Kristen untuk menjalankan otoritasnya di dalam kelas.

Fakta dan harapan jauh berbeda. Masalah yang terjadi merupakan akibat dari praktik guru dalam menjalankan otoritasnya di dalam kelas karena guru tidak memiliki dasar atau praktik yang benar dalam menjalankan otoritasnya. Setiap guru memiliki cara pandang sendiri dalam melakukan sebuah tindakannya di kelas. Harapan untuk otoritas guru di dalam kelas adalah guru mampu memiliki dasar pemahaman yang benar dalam menjalankan otoritasnya sebelum guru mempraktikkan otoritasnya di dalam kelas. Dasar yang benar mengenai otoritas seharusnya menghasilkan praktik yang benar dalam berotoritas.

Cara pandang guru Kristen yang benar terhadap otoritas membuat guru mampu menemukan akar masalah yang terdapat dalam fakta yang ditemukan. Akar 
masalah otoritas guru tersebut adalah kurangnya pemahaman yang benar tentang cara pandang terhadap otoritas di dalam kelas atau tidak adanya dasar kebenaran yang dipegang oleh guru dalam menjalankan otoritasnya. Landasan teori yang sudah dijelaskan mengenai cara pandang guru Kristen terhadap otoritas menjadi salah satu cara untuk mengatasi dan memperbaiki permasalahan yang terdapat dalam fakta tentang otoritas guru di dalam kelas. Dasar cara pandang guru terhadap otoritas di kelas, akan mempengaruhi tindakan guru dalam kegiatan mengajar di kelas. Oleh sebab itu, guru perlu untuk memahami cara pandang terhadap otoritas dengan benar sebelum melakukan sebuah tindakan di dalam kelas.

\section{KESIMPULAN}

Masalah-masalah otoritas guru yang terjadi di dalam kelas berakar dari cara pandang, dasar, dan motif yang digunakan keliru. Solusi untuk mengatasi hal tersebut adalah guru harus membangun cara pandang yang benar terhadap otoritas yang dimilikinya sehingga guru memiliki dasar yang kuat dan benar dalam mempraktikkan otoritasnya di kelas. Cara pandang guru Kristen yang benar terhadap otoritas dilihat dari kajian teologi sebagai dasar yaitu Allah adalah otoritas tertinggi dalam kerangka Kisah Agung, sehingga guru Kristen dapat menjalankan otoritasnya dengan baik. Kesimpulan yang dapat diambil dari penulisan ini adalah cara pandang guru terhadap otoritas mempengaruhi praktik tindakannya di kelas. Guru Kristen yang memiliki dasar cara pandang yang benar terhadap otoritas menghasilkan tindakan yang benar dalam menjalankan otoritasnya. Guru yang mampu menjalankan otoritas dengan benar adalah guru yang memiliki ketaatan penuh kepada otoritas tertinggi yaitu Allah. Guru akan menggunakan otoritasnya dengan rendah hati dan melihat otoritas tersebut sebagai anugerah yang harus dikerjakan sehingga dapat memuliakan Tuhan. Guru Kristen yang memiliki cara pandang yang benar mengenai otoritas dan menjalankannya dengan baik akan berdampak baik pada siswa. Oleh sebab itu, saran untuk penelitian selanjutnya dalam topik ini adalah perlu dilakukan penelitian kuantitatif yang mendukung dan membuktikan keterkaitan cara pandang dan praktik guru tentang otoritas secara lebih dalam di lapangan sehingga dapat melihat keadaan nyata yang terjadi. Peneliti akan lebih mendapat informasi lengkap 
mengenai latar belakang cara pandang guru, data-data yang menunjukkan kurangnya guru memiliki cara pandang yang benar terhadap otoritas sehingga peneliti akan lebih mudah mengkaji lebih dalam topik ini.

\section{Endnotes:}

${ }^{1}$ H. G. Panembahan, Pendidikan Agama Kristen Dalam Alkitab Dan Dunia Pendidikan Masa Kini (Yogyakarta: ANDI, 2012), 188.

2 W. Sanjaya, Strategi Pembelajaran Berorientasi Standar Proses Pendidikan (Jakarta: Kencana, 2011), 64.

${ }^{3}$ Isnarmi Moeis, Al Rafni, and Junaidi Indrawadi, "Otoritas Guru Dalam Konteks Pendidikan Kritis Di SMA Negeri Kota Padang," Jurnal Pendidikan Dan Kebudayaan 16, no. 4 (2010): 393, https://doi.org/https://doi.org/10.24832/jpnk.v16i4.470.

${ }^{4}$ Moeis, Rafni, and Indrawadi, "Otoritas Guru Dalam Konteks Pendidikan Kritis Di SMA Negeri Kota Padang."

${ }^{5}$ Louis Berkhof and Cornelius Van Til, Dasar Pendidikan Kristen: Ceramah-Ceramah Kepada GuruGuru Kristen, 1st ed. (Surabaya, Indonesia, 2004), 178.

${ }^{6}$ Berkhof and Van Til, Dasar Pendidikan Kristen: Ceramah-Ceramah Kepada Guru-Guru Kristen.

${ }^{7}$ Stephen. Tong, Arsitek Jiwa II (Surabaya: Momentum, 2006), 98.

${ }^{8}$ Faizatul Lutfia Yasmin, Anang Santoso, and Sugeng Utaya, "Hubungan Disiplin Dengan Tanggung Jawab Belajar Siswa," Jurnal Pendidikan: Teori, Penelitian, Dan Pengembangan 1, no. 4 (2016): 693.

${ }^{9}$ S. Yugo Hindarto, "KPAI Kecam Aksi Guru Aniaya Murid Di Pangkal Pinang," CNN Indonesia, 2017.

${ }^{10}$ David Martin Whitworth, Missio Dei and The Means of Grace: Theology of Participation (Eugene: Pickwick Publication, 2019), 16.

${ }^{11}$ Whitworth, Missio Dei and The Means of Grace: Theology of Participation.

${ }^{12}$ Yohanes Calvin, Institutio: Pengajaran Agama Kristen (Jakarta: Gunung Mulia, 2015), 42.

${ }^{13}$ Calvin, Institutio: Pengajaran Agama Kristen.

${ }_{15}^{14}$ A. A. Hoekema, Manusia: Ciptaan Menurut Gambar Allah (Surabaya: Momentum, 2008), 145.

${ }^{15}$ G.I. Williamson, Katekismus Singkat Westminster, Vol. I (Momentum, 2006), 120.

${ }^{16}$ Hoekema, Manusia: Ciptaan Menurut Gambar Allah.

${ }^{17}$ Hoekema.

${ }^{18}$ Hoekema.

${ }^{19}$ Punaji Setyosari, Metode Penelitian Pendidikan \& Pengembangan (Jakarta: Kencana, 2016), 117.

${ }^{20}$ A. M. Wolters, Pemulihan Ciptaan (Surabaya: Momentum, 2010), 2.

${ }^{21}$ M. Suardi, T. Ariprabowo, and Syofrianisda, Dasar-Dasar Pendidikan (Yogyakarta: Parama Ilmu, 2017), 85.

${ }^{22}$ R. W. Pazmino, Fondasi Pendidikan Kristen: Sebuah Pengantar Dalam Perspektif Injili (Bandung: BPK Gunung Mulia, 2012), 111.

${ }^{23}$ R. Stearns, Belum Selesai: Mengisi Lubang Di Dalam Injil Kita \& Memenuhi Panggilan Kita Di Dunia (Surabaya: Literatur Perkantas Jawa Timur, 2014), 38.

24 J. H. Prijanto, "Panggilan Guru Kristen Sebagai Wujud Amanat Agung Yesus Kristus Dalam Penanaman Nilai Alkitabiah Dalam Era Digital," A Journal of Language, Literature, Culture, and Education POLYGLOT 13, no. 2 (2017): 106.

${ }^{25}$ J. M. Yeats and J. Blase, Mari Berpikir Tentang Pandangan Dunia: Bagaimana Orang-Orang Memandang Tuhan? (Yogyakarta: Yayasan Gloria, 2011), 16.

${ }^{26}$ J. W. Lo, Seri Pemuridan Intensional: Panggilan Dan Harga Pemuridan (Tangerang: Universitas Pelita Harapan Press, 2018), 53.

${ }^{27}$ V. Montoro, "Professional Development for Christian Teachers: A Mixed Methods Study," The Journal of Applied Christian Leadership 7, no. 1 (2013): 61. 
${ }^{28}$ E. H. Palmer, Lima Pokok Calvinisme (Surabaya: Momentum, 2005), 190.

${ }^{29}$ Williamson, Katekismus Singkat Westminster, Vol. I.

${ }^{30}$ George R. Knight, Filsafat \& Pendidikan (Jakarta: Universitas Pelita Harapan Press, 2009), 247.

${ }^{31}$ Knight, Filsafat \& Pendidikan.

${ }^{32}$ Knight.

${ }^{33}$ Hoekema, Manusia: Ciptaan Menurut Gambar Allah.

${ }^{34}$ Musa S Tarigan, "Implikasi Penebusan Kristus Dalam Pendidikan Kristen,” Polyglot: Jurnal Ilmiah 15, no. 2 (2019): 204, https://doi.org/dx.doi.org/10.19166/pji.v15i2.1409.

${ }^{35}$ Tarigan, "Implikasi Penebusan Kristus Dalam Pendidikan Kristen."

${ }^{36}$ Jessica Novia Layantara, "Kemestian Dosa Dalam Inkarnasi Kristus,” Jurnal Amanat Agung 14, no. 1 (2018): 127.

${ }^{37}$ Mohamad Toha, "POWER, INFLUENCE, DAN AUTHORITY (Kasus Pada Kehidupan Politik Era Soekarno, Soeharto, Dan Habibie)," Jurnal Adzikra 3, no. 1 (2012): 104.

${ }^{38}$ G. I. Williamson, Katekismus Singkat Westminster, Vol. 2 (Surabaya: Momentum, 2006), 82.

${ }^{39}$ G. I. Williamson, Pengakuan Iman Westminster: Untuk Kelas Penelaahan (Surabaya: Momentum, 2017), 371.

${ }^{40}$ Wolters, Pemulihan Ciptaan.

${ }^{41}$ J. J. Juriaman and Dylmoon Hidayat, "Kepemimpinan Yang Menebus Di Sekolah Lentera Harapan Curug," A Journal of Language, Literature, Culture, and Education POLYGLOT 13, no. 2 (2017): 124.

${ }^{42}$ Stearns, Belum Selesai: Mengisi Lubang Di Dalam Injil Kita \& Memenuhi Panggilan Kita Di Dunia.

${ }^{43}$ S. Meade, Membentuk Hati, Mendidik Akal Budi: Renungan Keluarga Berdasarkan Katekismus Singkat Westminster (Surabaya: Momentum, 2011), 41.

${ }^{44}$ Kiki Debora and Chandra Han, "Pentingnya Peranan Guru Kristen Dalam Membentuk Karakter Siswa Dalam Pendidikan Kristen: Sebuah Kajian Etika Kristen,” Diligentia: Journal of Theology and Christian Education 2, no. 1 (2020): 1.

${ }^{45}$ Rudiyanto, Pandangan Hidup: Dalam Komunitas Murid Yesus (Semarang: Pustaka Muria, 2009), 52.

${ }^{46}$ Knight, Filsafat \& Pendidikan.

${ }^{47}$ Knight.

${ }^{48}$ C. S. Song, Yesus Dan Pemerintahan Allah (Jakarta: Gunung Mulia, 2010), 97.

49 A. E. Kristiyanto, Mengapa Bumi Menyembah Hyang Ilahi (Yogyakarta: Kanisius, 2008), 65.

${ }^{50}$ James R. Estep, Michael J Anthony, and Gregg R. Allison, A Theology for Christian Education (Nashville: B \& H Publishing Group, 2008), 219.

${ }^{51}$ Herman Bavinck, Reformed Dogmatics (Grand Rapids: Baker Academic, 2011), 579.

${ }^{52}$ Vincent Kalvin Wenno, “'INISIATIF UNTUK MENGASIHI' Membaca Etika Paulus Dalam Roma 12: 9-21 Serta Implikasinya Bagi Pembangunan Perdamaian,” KENOSIS: Jurnal Kajian Teologi 3, no. 2 (2017): 114-28.

${ }^{53}$ Estep, Anthony, and Allison, A Theology for Christian Education.

${ }^{54}$ Berkhof and Van Til, Dasar Pendidikan Kristen: Ceramah-Ceramah Kepada Guru-Guru Kristen.

55 A. A. Hoekema, Diselamatkan Oleh Anugerah (Surabaya: Momentum, 2008), 122.

${ }^{56}$ Prijanto, "Panggilan Guru Kristen Sebagai Wujud Amanat Agung Yesus Kristus Dalam Penanaman Nilai Alkitabiah Dalam Era Digital."

${ }^{57}$ Hoekema, Manusia: Ciptaan Menurut Gambar Allah.

${ }^{58}$ Louis Berkhof, Teologi Sistematika (Vol. 4) (Surabaya: Momentum, 2006), 5.

${ }^{59}$ Louis Berkhof, Teologi Sistematika (Vol. 3) (Surabaya: Momentum, 2005), 149.

${ }^{60}$ F. A. Wasukundi, "Pedagogy of Jesus for Modern World Christian Teachers," AFER 54, no. 3-4 (2012): 268.

\section{DAFTAR PUSTAKA}


Bavinck, Herman. Reformed Dogmatics. Grand Rapids: Baker Academic, 2011.

Berkhof, Louis. Teologi Sistematika (Vol. 3). Surabaya: Momentum, 2005.

—. Teologi Sistematika (Vol. 4). Surabaya: Momentum, 2006.

Berkhof, Louis, and Cornelius Van Til. Dasar Pendidikan Kristen: CeramahCeramah Kepada Guru-Guru Kristen. 1st ed. Surabaya, Indonesia, 2004.

Calvin, Yohanes. Institutio: Pengajaran Agama Kristen. Jakarta: Gunung Mulia, 2015.

Debora, Kiki, and Chandra Han. "Pentingnya Peranan Guru Kristen Dalam Membentuk Karakter Siswa Dalam Pendidikan Kristen: Sebuah Kajian Etika Kristen.” Diligentia: Journal of Theology and Christian Education 2, no. 1 (2020).

Estep, James R., Michael J Anthony, and Gregg R. Allison. A Theology for Christian Education. Nashville: B \& H Publishing Group, 2008.

Hindarto, S. Yugo. "KPAI Kecam Aksi Guru Aniaya Murid Di Pangkal Pinang." CNN Indonesia, 2017.

Hoekema, A. A. Diselamatkan Oleh Anugerah. Surabaya: Momentum, 2008.

-. Manusia: Ciptaan Menurut Gambar Allah. Surabaya: Momentum, 2008.

Juriaman, J. J., and Dylmoon Hidayat. “Kepemimpinan Yang Menebus Di Sekolah Lentera Harapan Curug." A Journal of Language, Literature, Culture, and Education POLYGLOT 13, no. 2 (2017): 123-32.

Knight, George R. Filsafat \& Pendidikan. Jakarta: Universitas Pelita Harapan Press, 2009.

Kristiyanto, A. E. Mengapa Bumi Menyembah Hyang Ilahi. Yogyakarta: Kanisius, 2008.

Layantara, Jessica Novia. "Kemestian Dosa Dalam Inkarnasi Kristus." Jurnal Amanat Agung 14, no. 1 (2018).

Lo, J. W. Seri Pemuridan Intensional: Panggilan Dan Harga Pemuridan. Tangerang: Universitas Pelita Harapan Press, 2018.

Meade, S. Membentuk Hati, Mendidik Akal Budi: Renungan Keluarga Berdasarkan 
Katekismus Singkat Westminster. Surabaya: Momentum, 2011.

Moeis, Isnarmi, Al Rafni, and Junaidi Indrawadi. "Otoritas Guru Dalam Konteks Pendidikan Kritis Di SMA Negeri Kota Padang." Jurnal Pendidikan Dan $\begin{array}{lllll}\text { Kebudayaan } & 16, & \text { no. } & 4 & \text { (2010): }\end{array}$ https://doi.org/https://doi.org/10.24832/jpnk.v16i4.470.

Montoro, V. "Professional Development for Christian Teachers: A Mixed Methods Study." The Journal of Applied Christian Leadership 7, no. 1 (2013): 54-67.

Palmer, E. H. Lima Pokok Calvinisme. Surabaya: Momentum, 2005.

Panembahan, H. G. Pendidikan Agama Kristen Dalam Alkitab Dan Dunia Pendidikan Masa Kini. Yogyakarta: ANDI, 2012.

Pazmino, R. W. Fondasi Pendidikan Kristen: Sebuah Pengantar Dalam Perspektif Injili. Bandung: BPK Gunung Mulia, 2012.

Prijanto, J. H. "Panggilan Guru Kristen Sebagai Wujud Amanat Agung Yesus Kristus Dalam Penanaman Nilai Alkitabiah Dalam Era Digital.” A Journal of Language, Literature, Culture, and Education POLYGLOT 13, no. 2 (2017): 99-107.

Rudiyanto. Pandangan Hidup: Dalam Komunitas Murid Yesus. Semarang: Pustaka Muria, 2009.

Sanjaya, W. Strategi Pembelajaran Berorientasi Standar Proses Pendidikan. Jakarta: Kencana, 2011.

Setyosari, Punaji. Metode Penelitian Pendidikan \& Pengembangan. Jakarta: Kencana, 2016.

Song, C. S. Yesus Dan Pemerintahan Allah. Jakarta: Gunung Mulia, 2010.

Stearns, R. Belum Selesai: Mengisi Lubang Di Dalam Injil Kita \& Memenuhi Panggilan Kita Di Dunia. Surabaya: Literatur Perkantas Jawa Timur, 2014.

Suardi, M., T. Ariprabowo, and Syofrianisda. Dasar-Dasar Pendidikan. Yogyakarta: Parama Ilmu, 2017.

Tarigan, Musa S. "Implikasi Penebusan Kristus Dalam Pendidikan Kristen." Polyglot: Jurnal Ilmiah 15, no. 2 (2019): 203-22. https://doi.org/dx.doi.org/10.19166/pji.v15i2.1409. 
Toha, Mohamad. "POWER, INFLUENCE, DAN AUTHORITY (Kasus Pada Kehidupan Politik Era Soekarno, Soeharto, Dan Habibie).” Jurnal Adzikra 3, no. 1 (2012): 99-111.

Tong, Stephen. Arsitek Jiwa II. Surabaya: Momentum, 2006.

Wasukundi, F. A. "Pedagogy of Jesus for Modern World Christian Teachers." AFER 54, no. 3-4 (2012): 262-84.

Wenno, Vincent Kalvin. “'INISIATIF UNTUK MENGASIHI' Membaca Etika Paulus Dalam Roma 12: 9-21 Serta Implikasinya Bagi Pembangunan Perdamaian.” KENOSIS: Jurnal Kajian Teologi 3, no. 2 (2017): 114-28.

Whitworth, David Martin. Missio Dei and The Means of Grace: Theology of Participation. Eugene: Pickwick Publication, 2019.

Williamson, G. I. Katekismus Singkat Westminster, Vol. 2. Surabaya: Momentum, 2006.

—. Pengakuan Iman Westminster: Untuk Kelas Penelaahan. Surabaya: Momentum, 2017.

Williamson, G.I. Katekismus Singkat Westminster, Vol. I. Momentum, 2006.

Wolters, A. M. Pemulihan Ciptaan. Surabaya: Momentum, 2010.

Yasmin, Faizatul Lutfia, Anang Santoso, and Sugeng Utaya. "Hubungan Disiplin Dengan Tanggung Jawab Belajar Siswa.” Jurnal Pendidikan: Teori, Penelitian, Dan Pengembangan 1, no. 4 (2016): 692-97.

Yeats, J. M., and J. Blase. Mari Berpikir Tentang Pandangan Dunia: Bagaimana Orang-Orang Memandang Tuhan? Yogyakarta: Yayasan Gloria, 2011. 